\title{
Analisis Stabilitas Lereng dengan Perkuatan Geocell Menggunakan Metode Elemen Hingga (PLAXIS 2D)
}

\author{
ARZUNNITA PRAMULANDANI, INDRA NOER HAMDHAN
}

\author{
Jurusan Teknik Sipil, Institut Teknologi Nasional Bandung \\ Email: arzunnitapramulandani@gmail.com
}

\begin{abstract}
ABSTRAK
Lereng adalah permukaan bumi yang membentuk sudut kemiringan tertentu dengan bidang horizontal. Salah satu tindakan penanganan bencana longsor pada lereng melakukan perkuatan lereng menggunakan bahan geosintetik seperti geocell. Penelitian ini bertujuan untuk menganalisis pengaruh geocell terhadap kestabilan lereng, sehingga dapat diketahui karakteristik pemasangan geocell yang dapat meningkatkan faktor keamanan suatu lereng. Penelitian ini melakukan variasi jarak antar vertikal geocell dengan spesifikasi geocell dan data tanah yang telah didapatkan untuk dilakukannya tahap pemodelan dengan perkuatan geocell sampai mendapatkan nilai faktor keamanan lebih besar dari nilai faktor keamanan minimum. Pemodelan dilakukan menggunakan program PLAXIS 2D. Perkuatan dengan geocell efektif digunakan pada tanah lempung, sehingga pemasangan jarak vertikal geocell yang paling efektif terdapat pada jarak 1 meter berdasarkan panjang geocell 6 m, dengan kemiringan lereng 1:1, kuat tarik 14,5 MPa dan didapatkan nilai SF lebih besar dari /batas minimum, semakin rapat pemasangan geocell mampu meningkatkan nilai faktor keamanan dengan rata-rata sebesar $7 \%$.
\end{abstract}

Kata kunci: faktor keamanan, geocell, stabilitas lereng, timbunan

\begin{abstract}
Slope is the surface of the earth that forms a certain angle of inclination with a horizontal plane. One of the prevention to overcome landslides on slopes is to strengthen slopes using geosynthetic materials such as Geocells. This study aims to analyze the effect of geocells on slope stability, so that the characteristics of geocell installation can be known which can increase the safety factor of a slope. This study varies the distance between vertical geocells with geocell specifications and soil data that has been obtained for the modeling phase with geocell reinforcement to obtain the safety factor value greater than the minimum safety factor value. Modeling is done using 2D PLAXIS program. Reinforcement with geocells is effectively used on clay soils, so that the most effective vertical geocell spacing is at a distance of 1 meter based on the geocell length of $6 \mathrm{~m}$, with a slope of 1: 1 , tensile strength $14.5 \mathrm{MPa}$ and the $S F$ value is greater than / minimum limit, the denser the geocell installation can increase the value of the safety factor by an average of $7 \%$.
\end{abstract}

Keywords: safety factor, geocell, slope stability, embankment 


\section{PENDAHULUAN}

Perkuatan lereng menggunakan geosintetik mempunyai umur rencana yang cukup lama, mendukung beban yang besar dan memiliki fungsi sebagai separator, filter, proteksi, dan perkuatan (Rahardjo, P. P., 2002). Penelitian ini menganalisis stabilitas lereng yang diperkuatan geocel/dengan memvariasikan jarak vertikal geocel/ untuk mengetahui nilai faktor keamanan. Tujuan penelitian ini adalah menganalisis kestabilan lereng yang diperkuat geocell dengan adanya pengaruh jarak vertikal pemasangan geocell. Pemodelan dialakukan menggunakan software PLAXIS 2D yang berbasis elemen hingga. Mehdipour, I., Ghazavi, M. \& Moayed, R. Z. (2013), melakukan studi numerik tentang analisis stabilitas lereng yang diperkuat geocell dengan mempertimbangkan efek lentur dan Dash, S. K., Krishnaswamy, R. N. \& Karpurapu, R. (2001), melakukan variasi jumlah lapisan geocell sangat berpengaruh terhadap nilai faktor keamanan, semakin banyak lapisan geocel/ yang digunakan maka makin berpengaruh terhadap besarnya faktor keamanan. Geocel/ mampu meningkatkan nilai faktor keamanan dan mengurangi deformasi pada lereng jika adanya beban gempa yang terjadi pada lereng.

\section{TINJAUAN PUSTAKA}

\subsection{Geocell sebagai Perkuatan Tanah}

Upaya yang digunakan untuk perkuatan struktur lereng yaitu menggunakan geosintetik dengan tipe geocell yang sengaja dibuat oleh manusia yang terbuat dari bahan polymer (sejenis plastik). Geocel/ ini digunakan dalam teknik perkuatan tanah sebagai dinding penahan tanah dan stabilitas lereng. Analisis pada penelitian ini memilih menggunakan geocel/ sebagai bahan perkuatan pada lereng dengan memvariasikan pemasangan jarak antar vertikal geocell. Aplikasi geocel/ untuk perkuatan yaitu dapat untuk timbunan, konstruksi jalan, pondasi, jalan kereta api, dinding penahan tanah, dan proteksi lereng dan erosi kontrol (Departemen Pekerjaan Umum, 2009). Diperkirakan geocell ini cukup efektif untuk perkuatan lereng dan mengurangi deformasi pada lereng yang lemah terjadi longsor, sehingga jarak vertikal geocell dapat meningkatkan nilai faktor kemanan pada lereng. Geoce//merupakan produk tiga dimensi yang berbentuk seperti sarang lebah yang terbuat dari bahan polimer (PT. Pandu Equator Prima Geosynthetics Engineering, 2020). Geocel/ memiliki bentuk dengan diameter dan tinggi yang berbeda-beda. Geocell adalah panel tiga dimensi yang ringan dan flexible (PT. Pandu Equator Prima Geosynthetics Engineering, 2020). Material utamanya adalah High-Density Polyethylene (HDPE) strip yang diikat dengan cara ultrasonik sehingga didapatkan konfigurasi yang kuat (PT. Pandu Equator Prima Geosynthetics Engineering, 2020). Berdasarkan permukaannya terdapat dua tipe Geocell yaitu halus (smooth) dan kasar (textured). Pemodelan dengan pemasangan geocell yang ditimbun dalam tanah dan dihamparkan secara horizontal memotong pada bidang gelincir yang kritis maka geocell akan meningkatkan gaya yang menahan longsor pada lereng. Jarak pemasangan geocel/ dapat diatur sesuai kebutuhan dan tingkatan kritisnya suatu lereng.

\subsection{Analisis Stabilitas Lereng}

Analisis stabilitas lereng yaitu menentukan faktor keamanan dari bidang longsor. Faktor keamanan (FK) didefinisikan sebagai nilai perbandingan antara gaya yang menahan dan gaya yang menggerakan (SNI 8460:2017). Nilai-nilai faktor keamanan (FK) atau safety factor(SF) untuk menilai kestabilan suatu lereng mengacu pada SNI 8460:2017 kondisi lereng dikatakan aman jika FK $>1,25$ dengan satu jenis tanah yang menunjukkan lereng stabil. Pemodelan tersebut akan menghasilkan nilai faktor keamanan dengan menggunakan metode shear strength reduction ( $p$ hi-c reduction) yaitu suatu metode yang dimanfaatkan untuk menentukan suatu nilai SF dan umumnya pada pendekatan-pendekatan elemen hingga. Pendekatan yang utama dari elemen hingga adalah stress = matriks kekakuan (stiffness matrix) dikalikan 
dengan regangan (strains) (Cook, R. D., 1990). Dengan $c$ atau $\phi$ (phi) (shear strength) tanah di-reduce akan mempengaruhi input dan output dari matriks-matriks tersebut sehingga dengan suatu pendekatan tertentu akan menghasilkan suatu nilai safety factor yang akan konvergen pada suatu batasan tertentu (galat/jumlah interaksi maksimum).

Nilai SF yang dihasilkan akan berhubungan dengan berbagai macam variable yaitu steps atau langkah interasi, time, displacement, water pressure (Brinkgreve, R. B. J., 2016). Dengan persamaan yang digunakan untuk mendapatkan nilai SF yaitu ditunjukan pada Persamaan 1. Pemodelan ini juga menganalisis stabilitas jangka pendek (short term) atau selesai konstruksi biasanya menggunakan tegangan total analisis (TSA), atau disebut juga dengan kondisi undrained. Kondisi ini terjadi karena waktu pembebanan kecepatannya lebih cepat dari keluarnya air pori. Dengan parameter yang digunakan $(c)$ kohesi dan $(\phi)$ phi untuk menghasilkan nilai SF. Sedangkan pada kondisi jangka panjang (long term) atau kondisi drained analisis yang digunakan tegangan efektif stress (ESA).

Pada tegangan efektif analisis pembebanannya lebih lama dari keluarnya air pori. Sehingga dalam waktu jangka lama tekanan air pori tereduksi yang menyebabkan kuat geser tanah dan faktor keamanan meningkat. Parameter yang digunakan dalam tegangan efektif $\left(c^{\prime}\right)$ dan $\left(\phi^{\prime}\right)$ yang ditentukan dari analisis stabilitas jangka pendek (short term) dengan derajat konsolidasi pada saat tertentu dimana $U$ antara $(0-100) \%$ yang bermaksud untuk mengetahui penurunannya dalam waktu tertentu, dengan $U=90 \%$ dan menggunakan persamaan ditunjukan pada Persamaan 2. Analisis gempa yang digunakan untuk merencanakan bangunan tahan gempa, menggunakan metode Pseudo Statik adalah merubah gaya yang timbul akibat beban gempa yang berbentuk dinamik menjadi statik dengan menerapkan gaya lateral yang bekerja melalui pusat massa, bertindak ke arah luar lereng dan menggunakan koefisien seismik yang didapatkan dari percepatan puncak dari permukaan ( $P G A)$ dengan penentuan kelas situs pada lokasi tanah tersebut (SNI 8460:2017).

$$
\sum M_{S F}=\frac{\tan \phi_{\text {available }}}{\tan \phi_{\text {failure }}}=\frac{C_{\text {available }}}{C_{\text {failure }}}
$$

halmana:

$\Sigma M_{S F} \quad=$ faktor keamanan,

$\phi_{\text {available }}=$ sudut geser dalam tanah $\left[^{\circ}\right]$,

$\phi_{\text {failure }}=$ sudut geser dalam tanah tereduksi $\left[{ }^{\circ}\right]$,

c available $=$ kohesi tanah $[\mathrm{kPa}]$,

c $c_{\text {failure }} \quad=$ kohesi tanah tereduksi $[\mathrm{kPa}]$.

$$
t_{90}=\frac{0,848 \times H}{C_{v}}
$$

halmana:

$\begin{array}{ll}t_{90} & =\text { waktu penurunan sampai } 90 \% \text { [detik], } \\ H & =\text { tinggi rata-rata sampel }[\mathrm{m}], \\ C_{v} & =\text { koefisien konsolidasi }\left[\mathrm{m}^{2} / \text { detik]. }\right.\end{array}$

\section{METODOLOGI PENELITIAN}

Tanah yang digunakan pada pemodelan ini adalah tanah lempung yang berlokasi di Tanah Merah, Desa Penaga, Kec. Teluk Bintan, Tanjung Pinang. Setelah didapatkan data tanah maka dilakukan pemodelan lereng tanpa perkuatan geocel/menggunakan Software PLAXIS 2D yang menghasilkan faktor keamanan yang kritis. Parameter tersebut dapat dilihat pada Tabel $\mathbf{1}$ 
yang digunakan sebagai parameter tanah untuk pemodelan analisis stabilitas jangka pendek (short term), jangka panjang (long term) dan gempa, pada parameter long term yaitu menggunakan $\left(c^{\prime}\right)$ dan $\left(\phi^{\prime}\right)$ yang didapatkan dari analisis jangka pendek (short term) setelah dikonsolidasikan $90 \%$ pada pemodelan di Software PLAXIS 2D.

Tabel 1. Data Parameter Tanah (short term)

\begin{tabular}{cccccccc}
\hline Jenis Tanah & $\begin{array}{c}\gamma_{\text {unsat }} \\
{\left[\mathbf{k N} / \mathbf{m}^{3}\right]}\end{array}$ & $\begin{array}{c}\gamma_{\text {sat }} \\
{\left[\mathbf{k N} / \mathbf{m}^{3}\right]}\end{array}$ & $\begin{array}{c}\boldsymbol{E} \\
{\left[\mathbf{k N} / \mathbf{m}^{\mathbf{2}}\right]}\end{array}$ & $\begin{array}{c}\boldsymbol{c} \\
{\left[\mathbf{k N} / \mathbf{m}^{2}\right]}\end{array}$ & $\begin{array}{c}\boldsymbol{\phi} \\
{\left[{ }^{\circ}\right]}\end{array}$ & $\begin{array}{c}\boldsymbol{\psi} \\
{\left[{ }^{\circ}\right]}\end{array}$ & Model Material \\
\hline Lempung & 16,279 & 10,915 & 10.000 & 7,5 & 7,750 & 0 & $M-C$ \\
\hline
\end{tabular}

Geocel/saat digunakan sebagai bahan perkuatan bekerja mengandalkan kuat tarik. Pada saat geocel/ tersebut tertarik, maka akan berdeformasi dan mengalami perpanjangan (elongasi). Pemodelan yang dilakukan menggunakan Software PLAXIS 2D membutuhkan nilai kuat tarik dari material geocell tersebut. Data spesifikasi geocell yang digunakan membentuk seperti sarang lebah dan memiliki parameter seperti pada Tabel $\mathbf{2}$.

Tabel 2. Data Parameter Geocell

\begin{tabular}{lccc}
\hline Keterangan & Kemiringan Lereng & $\begin{array}{c}\text { Kuat Tarik } \\
{[\mathrm{MPa}]}\end{array}$ & $\begin{array}{c}\text { Elongasi } \\
{[\%]}\end{array}$ \\
\hline HDPE Geocell & $1 \mathrm{~V}: 1 \mathrm{H}, 1 \mathrm{~V}: 1,5 \mathrm{H}$, dan $1 \mathrm{~V}: 2 \mathrm{H}$ & 33 & 10 \\
\hline
\end{tabular}

Geocell merupakan elastic material serta memiliki data spesifikasi yang harus di-input pada Software PLAXIS 2D yaitu nilai $E A$ (normal stiffness) yang dihasilkan dari kuat tarik izin geocell $\left(P_{i z i n}\right)$ dibagi dengan nilai elongasi $(\varepsilon)$. Nilai kuat tarik izin yang digunakan yaitu $33 \mathrm{MPa}$, sedangkan nilai elongasi yang digunakan yaitu sebesar $10 \%$ yang diambil berdasarkan brosur produk geocell (Anhui Elite Industrial Co.,Itd., 2020). Nilai EA dapat dhitung dengan cara membagi nilai kuat tarik izin dengan nilai elongasi, sehingga didapatkan nilai $E A$ adalah sebesar $330 \mathrm{MPa}$.

Lokasi data tanah yang diambil yaitu Tanah Merah; Desa Penaga; Kec. Teluk Bintan, Kab. Bintan dengan koordinat lokasi yaitu latitude 0,5427 dan longitude 104,272. Diperoleh nilai percepatan puncak dipermukaan $(P G A) 0,0379 g$; nilai $P G A$ didapatkan dari desain spektra Indonesia atau response spectrum Puskim. Dengan faktor keamanan $>1,1$. Nilai koefisien situs untuk percepatan puncak mengacu pada klasifikasi situs $\left(F_{P G A}\right)$ yang berada di SNI $8460: 2017$, dengan jenis tanah lempung nilai $F_{P G A}$ yang digunakan yaitu 2,4 . Nilai koefisien seismik $\left(k_{h}\right)$ dapat dihitung menggunakan Persamaan $\mathbf{3}$ dan untuk koefisien gempa $(a)$ dapat dihitung menggunakan Persamaan 4.

$$
k_{h}=0,5 \times P G A
$$

halmana:

$k_{h} \quad=$ koefisien seismik,

$P G A=$ percepatan puncak dipermukaan $[g]$.

$$
a=k_{h} \times F_{P G A}
$$

halmana:

a = koefisien gempa $[g]$,

$F_{P G A} \quad=$ jenis tanah. 
Berdasarkan dari Persamaan 3 dan Persamaan 4 di atas, maka data yang di-input pada PLAXIS 2D untuk beban gempa pada pemodelan ini yaitu sebesar $0,0455 g$ arah horizontal yang dititik beratkan pada kondisi yang lemah terhadap beban gempa. Data yang telah didapatkan akan di-input pada software PLAXIS 2D sebagai parameter geocel/ dan parameter tanah. Pada pemodelan ini juga dilakukan jenis mesh dan melakukan pemodelan tanpa perkuatan terlebih dahulu untuk mendapatkan nilai SF di bawah nilai minimal dari Standar Nasional Indonesia (SNI) lalu dilakukannya pemodelan dengan variasi jarak vertikal dan dilakukannya pembahasan setelah mendapatkan nilai SF yang telah diperkuat.

\section{ANALISIS DAN PEMBAHASAN}

\subsection{Pemodelan Geometri Lereng}

Lereng yang dimodelkan pada software PLAXIS 2D merupakan lereng yang dilakukan penimbunan hingga ketinggian mencapai 10 meter, tinggi timbunan lereng 4 meter, lebar pada kaki lereng 25 meter dan lebar pada bagian atas lereng 8 meter, serta kedalaman tanah dari kaki lereng setinggi 6 meter. Pemodelan ini dilakukan dengan jenis tanah lempung. Pada pemodelan ini pemasangan geocel/ dipasang secara horizontal yang divariasikan jarak vertikal geocel/-nya dengan maksud untuk mengetahui pengaruh jarak pemasangan geocell pada kenaikan faktor keamanan lereng. Jarak yang dilakukan pada pemodelan ini dari mulai paling rapat, sedang dan renggang, yaitu 0,2 meter; 0,5 meter; dan 1 meter. Pemodelan geometri lereng yang telah dilakukan pada PLAXIS 2D dapat dilihat pada Gambar 1.

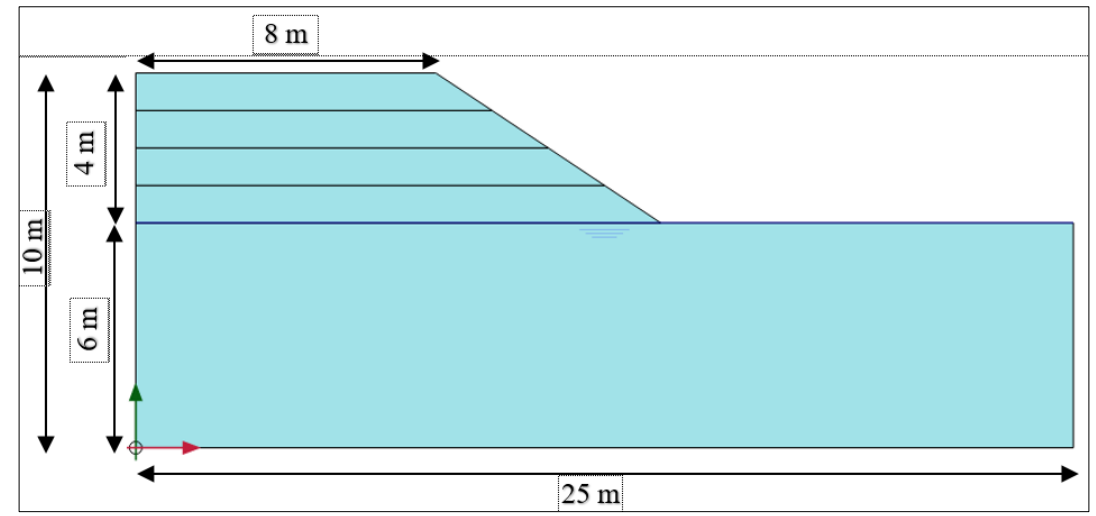

Gambar 1. Model geometri lereng

\subsection{Penentuan Jenis Mesh}

Penentuan jenis mesh pada software PLAXIS 2D menentukan kehalusan pembagian jaringanjaringan elemen yang menghubungkan node-node pada model yang ditinjau, serta ketelitian dari hasil analisis, semakin rapat jaringan elemen dan halus mesh maka hasil perhitungan akan semakin akurat. Pemodelan dilakukan percobaan di setiap jenis mesh apabila nilai faktor keamanan $>1$ maka jenis mesh tersebut akan digunakan untuk pemodelan selanjutnya.

Setelah semua jenis mesh dilakukan maka nilai SF pada setiap jenis mesh akan menentukan jenis mesh yang akan digunakan pada penelitian pemodelan. Berikut adalah grafik perbandingan antara jenis mesh dengan nilai faktor keamanan yang disajikan pada Gambar $\mathbf{2}$ dan pada Tabel $\mathbf{4}$ jenis mesh dan nilai SF.

Berdasarkan pada Gambar 2 perbandingan jenis mesh terhadap nilai faktor kemanan, nilai SF pada rifine global hasilnya mendekati nilai SF mesh very fine, maka jenis mesh yang digunakan pada penelitian pemodelan ini menggunakan jenis mesh very fine dan berlaku untuk pemodelan berikutnya. 


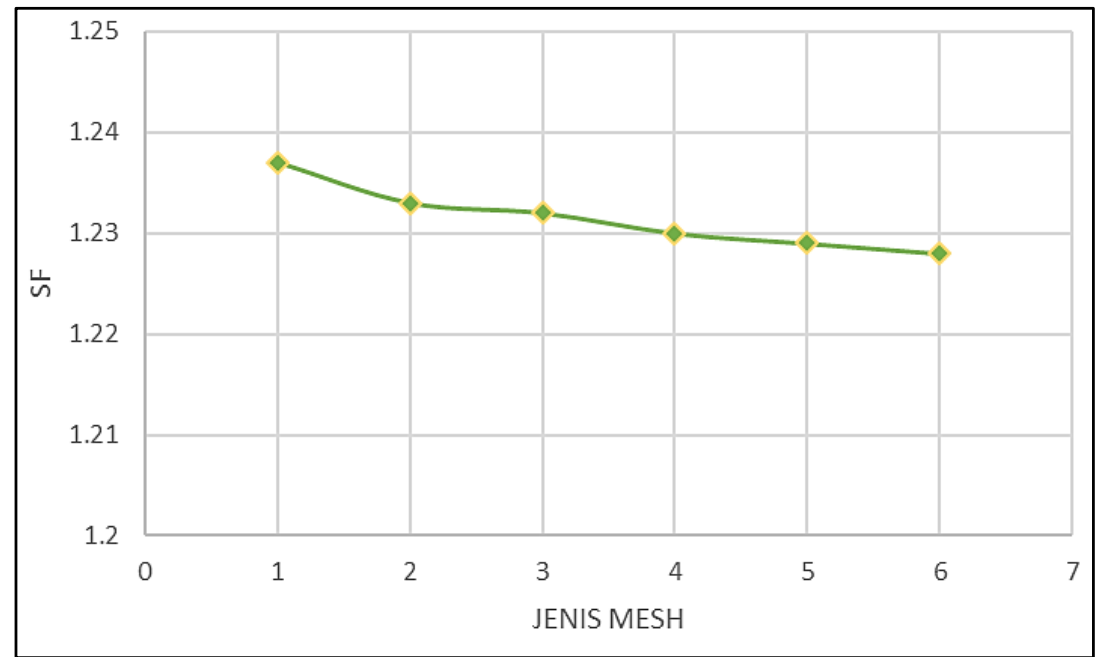

Gambar 2. Grafik perbandingan antara jenis mesh dengan nilai faktor keamanan

Tabel 4. Nilai SF Berdasarkan Jenis Mesh

\begin{tabular}{cc}
\hline Jenis Mesh & Faktor Keamanan \\
\hline Very Coarse & 1,237 \\
\hline Coarse & 1,233 \\
\hline Medium & 1,232 \\
\hline Fine & 1,230 \\
\hline Very Fine & 1,229 \\
\hline Refined Very Fine & 1,228 \\
\hline
\end{tabular}

\subsection{Analisis Stabilitas Lereng dan Pembahasan}

Analisis stabilitas lereng timbunan yang dilakukan pada penelitian ini, memodelkan dengan kondisi lereng tanpa perkuatan dan lereng setelah diperkuat. Pemodelan tersebut dilakukan untuk mengetahui nilai faktor keamanan dan bidang gelincir yang terjadi.

Analisis pemodelan lereng sebelum dilakukannya perkuatan yaitu untuk mengetahui nilai SF awal, sehingga dapat diketahui kondisi lereng yang memiliki bagian paling kritis untuk menentukan bagian mana yang tepat untuk diperkuat dan menghasilkan nilai faktor keamanan yang stabil. Mengacu pada SNI 8460:2017 kondisi lereng dapat dikatakan aman jika memiliki nilai faktor keamanan $\geq 1,25$ dengan satu jenis tanah. Hasil pemodelan lereng pada kondisi eksisting menggunakan Program PLAXIS 2D didapatkan nilai faktor keamanan kurang dari faktor keamanan izin, sehingga dibutuhkan perkuatan untuk menstabilkan lereng yang ditinjau. Berikut adalah hasil bidang gelincir yang dihasilkan dengan perbedaan kemiringan, dapat dilihat pada Gambar 3.

Berdasarkan Gambar 3 hasil analisis lereng sebelum diberikan perkuatan dengan kemiringan 1:1 dihasilkan nilai SF 1,229; kemiringan 1:1,5 nilai SF 1,234 dan kemiringan 1:2 menghasilkan nilai SF sebesar 1,235; ketiga jenis kemiringan yang dilakukan menggunakan mesh very fine. Pengaruhnya tiga kemiringan yang dilakukan terjadi pada nilai faktor keamanannya yang berbeda. Kemiringan yang landai akan memiliki nilai faktor keamanan lebih aman, dan pada kemiringan yang curam besar kemungkinannya akan terjadi longsor serta nilai faktor keamanannya lebih kecil dari pada kemiringan yang landai. 


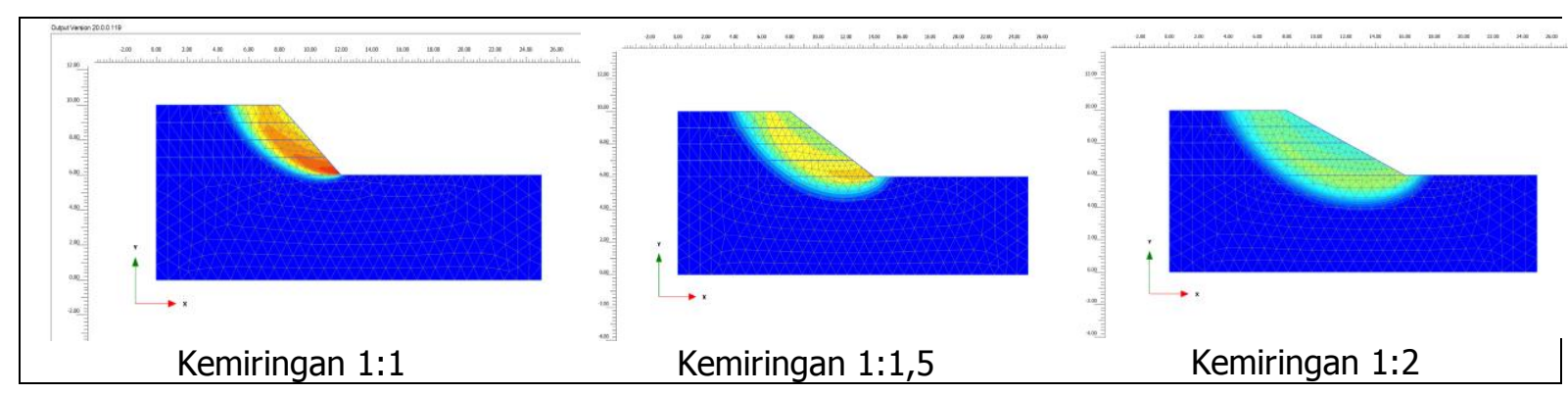

Gambar 3. Bidang gelincir tanpa perkuatan

Pemodelan geocel/ sebagai perkuatan divariasikan dengan cara pemasangan atau konfigurasi geocell dan jarak spasi antar vertikalnya. Panjang geocell yang akan digunakan sebagai perkuatan yaitu sepanjang 6 meter karena sudah memotong bidang lemah pada bidang gelincirnya sebelum diperkuat sehingga ditambahkan panajang geocellnya mengasilkan nilai SF yang sudah tidak berpengaruh kembali terhadap kenaikan nilai SF pada lereng dan dipasang geocell tepat pada bidang yang lemah atau rawan terjadinya runtuh sebelum diperkuat. Perkuatan menggunakan geocell dipasang dan dihamparkan pada lereng yang rawan terhadap longsor dengan mempertimbangkan pemasangan jarak vertikal geocell sebelum dilakukan penimbunan.

Jarak vertikal geocel/ yang digunakan sebagai variasi pada pemodelan penelitian ini terdapat tiga macam jarak, yaitu 0,2 m; 0,5 m; dan $1 \mathrm{~m}$. Analisis yang dilakukan adalah mengetahui pengaruh jarak vertikal antar geocell terhadap nilai faktor keamanan. Grafik dan model geometri lereng dengan perkuatan geocell disajikan pada Gambar 4 yaitu kondisi lereng setelah diperkuat menggunakan geocel/ dengan variasi jarak vertikal geocell.

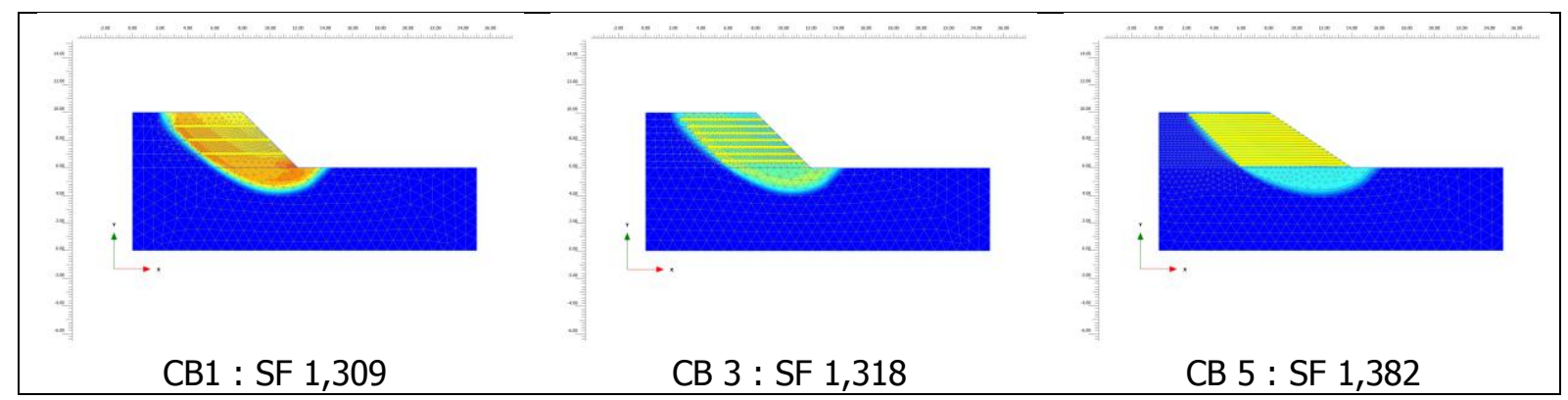

Gambar 4. Kemiringan 1:1 perkuatan dengan geocel/ dan variasi jarak vertikal 1 meter; 0,5 meter; dan 0,2 meter

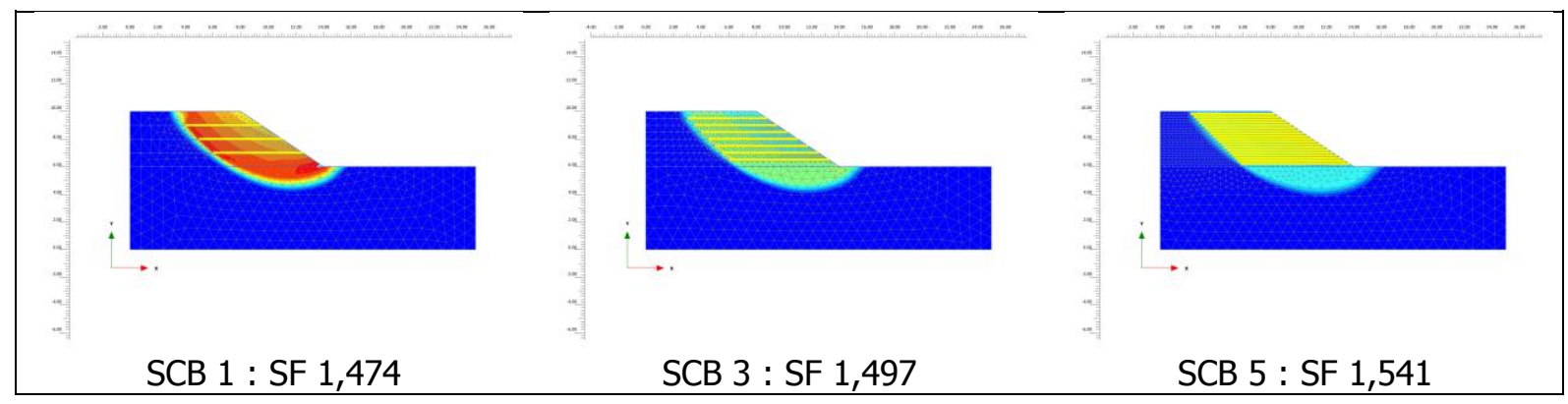

Gambar 5 Kemiringan 1:1,5 perkuatan dengan geocell dan variasi jarak vertikal 1 meter; 0,5 meter; dan 0,2 meter 


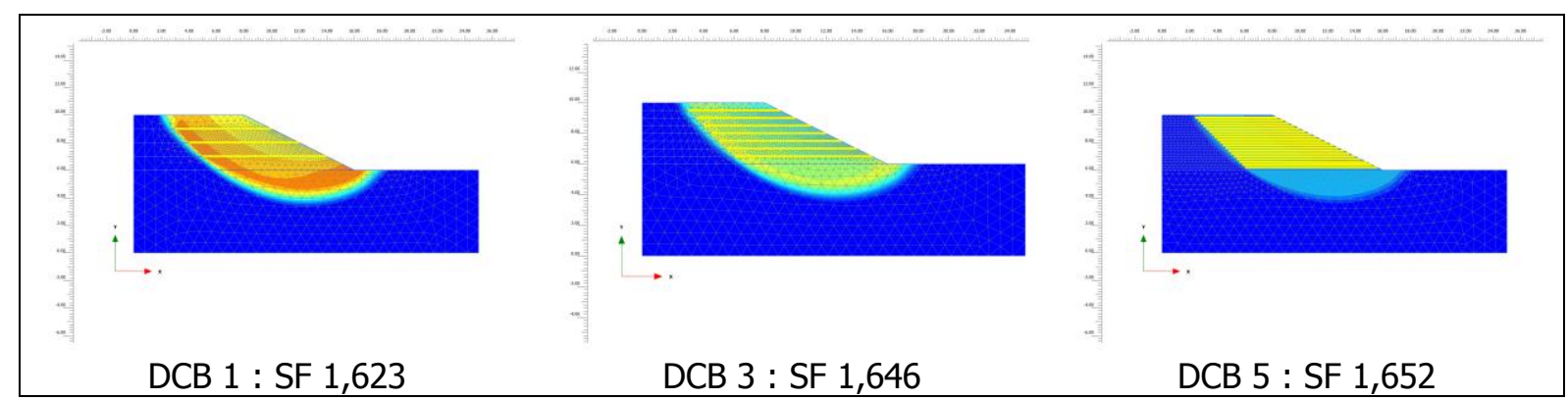

Gambar 6. Kemiringan 1:2 perkuatan dengan geocell dan variasi jarak vertikal 1 meter; 0,5 meter; dan 0,2 meter

Berdasarkan gambar yang telah disajikan Gambar 4, Gambar 5 dan Gambar 6 menunjukan bahwa kemiringan lereng mempengaruhi besarnya faktor keamanan. Jarak pemasangan geoce//menjadi salah satu variasi pada penelitian ini dikarenakan untuk mengetahui pengaruh pemasangan geocel/ terhadap peningkatan nilai faktor keamanan yang terjadi. Semakin jauh pemasangan antara geocell satu dengan yang lainnya maka akan mengakibatkan keadaan yang kritis pada lereng, namun apabila geocell dipasang semakin rapat kenaikan terhadap besarnya nilai faktor keamanan dapat meningkat sebesar $7 \%$ dan geocell akan memberikan perkuatan dan kestabilan pada lereng tersebut.

Pemasangan jarak vertikal geocell ini mempengaruhi terhadap bidang gelincir, dengan pemasangan geocell yang renggang atau dikatakan jauh antara jarak geocell satu dengan yang berikutnya akan menghasilkan bidang gelincir yang memiliki warna merah seperti pada Gambar 4, Gambar 5 dan Gambar 6 yang dihasilkan di model CB 1, SCB1, dan DCB 1, yang artinya tanah tersebut masih mengalami pergeseran dan memiliki nilai displacement terbesar, pada pemasangan geocell semakin rapat akan mengasilkan tanah yang padat atau mengurangi adanya pergeseran pada tanah seperti yang dihasilkan di model CB 5, SCB 5 dan DCB 5, biasanya hasil yang terdapat pada gambar bidang gelincir ditandai dengan warna biru. Dengan kemiringan yang berbeda dan pemasangan jarak vertikal geocell yang berbeda juga terjadi perubahan warna pada bidang gelincirnya secara signifikan, maka pemasangan geocell dengan mempertimbangkan jaraknya sangat berpengaruh pada nilai SF-nya dan juga mempengaruhi bidang gelincirnya.

Pemasangan geocell yang rapat mampu menstabilkan lereng yang rawan akan terjadinya longsor sehingga menjadi lereng yang aman, nilai faktor kemanannya pun termasuk kriteria lereng yang aman dengan mengacu pada nilai faktor keamanan minimal yang telah ditetapkan oleh SNI 8460:2017. Gambar 7 dan Gambar 8 menunjukan perbandingan antara jarak vertikal geocel/ dengan nilai $S F$ berdasarkan kuat tarik dan konfigurasi geocell. Masing-masing gambar yang memilki tiga garis grafik dengan warna garis yang berbeda menunjukan perbedaan kemiringan dan jarak vertikal geocell yang menyatakan bahwa semakin rapat geocell dipasang maka akan sangat berpengaruh pada kenaikan nilai SF atau kestabilan keamanan lereng, sehingga jarak paling rapat sangat efektif untuk digunakan jika ditinjau dalam segi hal keamanan pada penelitian model ini. Kenaikan nilai SF pada grafik tersebut dipengaruhi oleh adanya pemasangan geocell dengan memvariasikan jarak vertikalnya sehingga kerapatan geocell dapat berperan penting terhadap kestabilan lereng yang mengakibatkan nilai SF-nya meningkat.

Hasil analisis perkuatan lereng dengan variasi jarak tersebut diketahui bahwa semakin besar spasi vertikal antar geocell nilai faktor keamanan yang dihasilkan akan semakin kecil dan keadaan lereng akan semakin kritis. Hal tersebut terjadi karena pada saat spasi vertikal antar geocell semakin besar, maka tegangan tarik untuk menahan gaya longsor semakin kecil. 
Semakin kecil spasi vertikal antar geocel/menghasilkan nilai SF yang lebih besar. Pemasangan geocell ini sangat cepat, fleksibel dan sederhana dalam aplikasi pemasangan di lapangan sehingga memangkas waktu kerja.

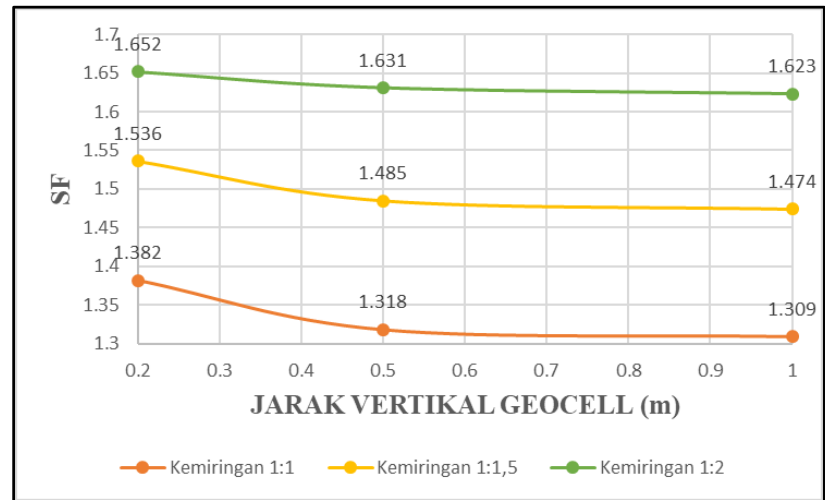

Gambar 7. Grafik pengaruh jarak vertikal geocel/ terhadap kenaikan SF dengan konfigurasi horizontal dan kuat tarik $33 \mathrm{kN} / \mathrm{m}$

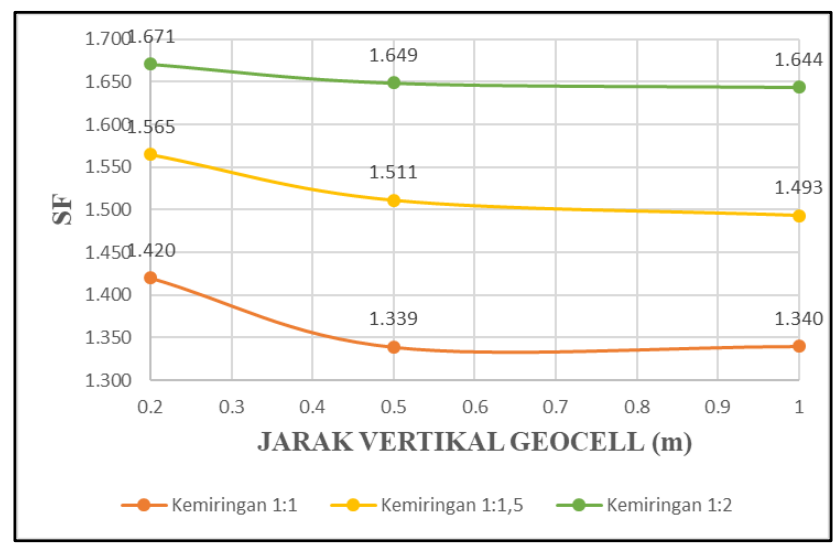

Gambar 8. Grafik pengaruh jarak vertikal geocel/ terhadap kenaikan SFdengan konfigurasi kombinasi dan kuat tarik $33 \mathrm{kN} / \mathrm{m}$

Penelitian pemodelan dengan memvariasikan jarak vertikal geocell, juga melakukan analisis pada kondisi short term atau jangka pendek, long term atau jangka panjang, dan getaran yang diakibatkan oleh adanya gempa. Kondisi short term pada software PLAXIS 2D menggunakan calculation type plastic dengan kondisi undrained. Kondisi ini terjadi karena waktu pembebanan kecepatannya lebih cepat dari keluarnya air pori. Kasus undrained terjadi pada tanah lempung, proses keluarnya air pori pada tanah lempung sangat lama jika dibandingkan dengan tanah pasir. Sedangkan pada kondisi long term atau jangka panjang, menggunakan calculation type consolidation dengan kondisi drained. Pada kondisi ini pembebanan nya lebih lama dari keluarnya air pori. Biasanya menggunkan analisis tegangan efektif yang dimana parameter didapatkan pada uji triaxial test. Pengaruh pemodelan dengan mengecek pada kondisi long term dapat meningkatkan nilai faktor keamanan pada lereng, sehingga tanah timbunan pada lereng dapat lebih padat dengan sedikitnya air pori, dan menghasilkan nilai $S F$ lebih besar dari pada kondisi short term dikarenakan pemodelan dilakukan konsolidasi dengan jangka waktu selama tiga hari, dengan maksud agar tanah timbunan menjadi lebih padat dan menghasilkan nilai kestabilan pada lereng yang aman.

Beban gempa yang terjadi pada pemodelan ini diberikan pada titik lemah lereng. Yang akan menimbulkan getaran sehingga memberikan kemungkinan akan terjadi longsor. Pada analisis ini seberapa kuat lereng yang perkuatan menggunakan geocell mampu menahan getaran 
gempa. Sehingga kekutan pada geocel/ ini dapat dibuktikan. Geometri lereng disajikan pada Gambar 9.

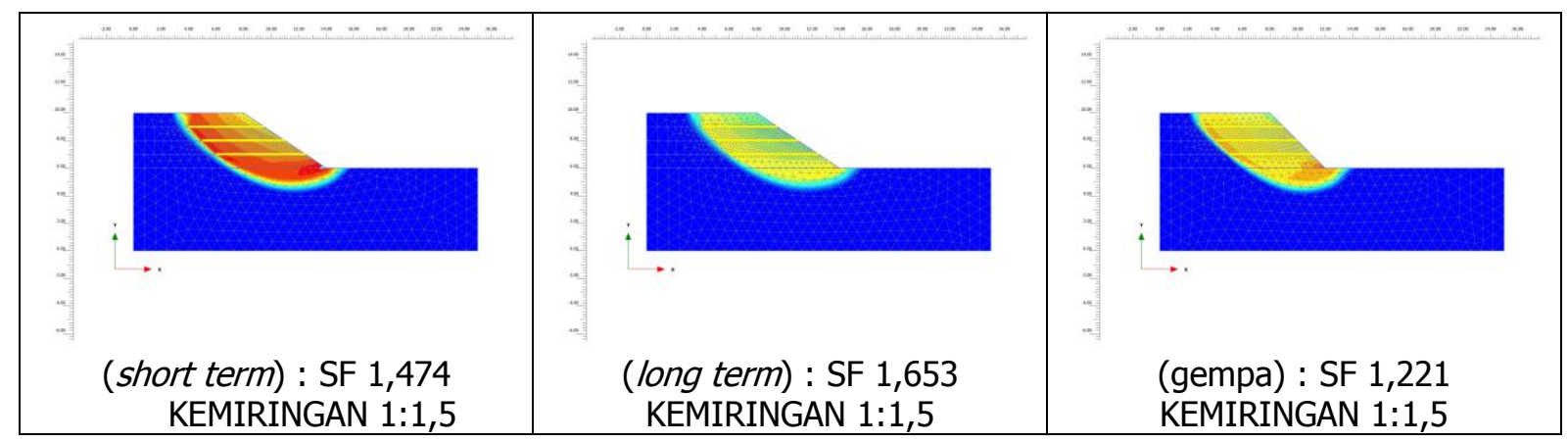

Gambar 9. Pengaruh kondisi short term, long term dan beban gempa pada kemiringan 1:1,5 dengan jarak vertikal geocell 1 meter

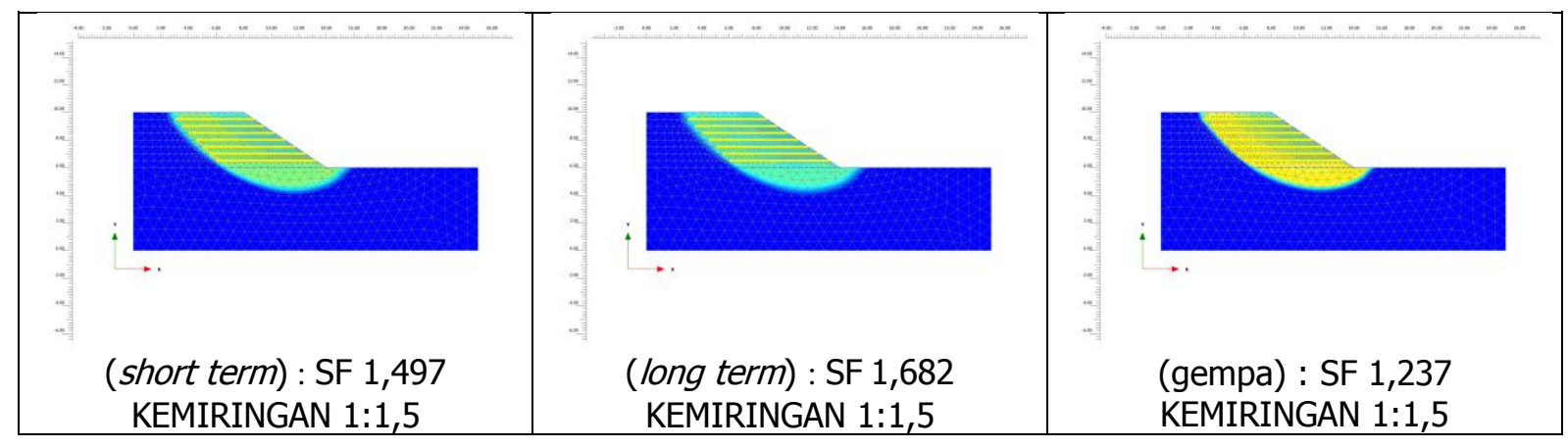

Gambar 10. Pengaruh kondisi short term, long term dan beban gempa pada kemiringan 1:1,5 dengan jarak vertikal geocel/ 0,5 meter

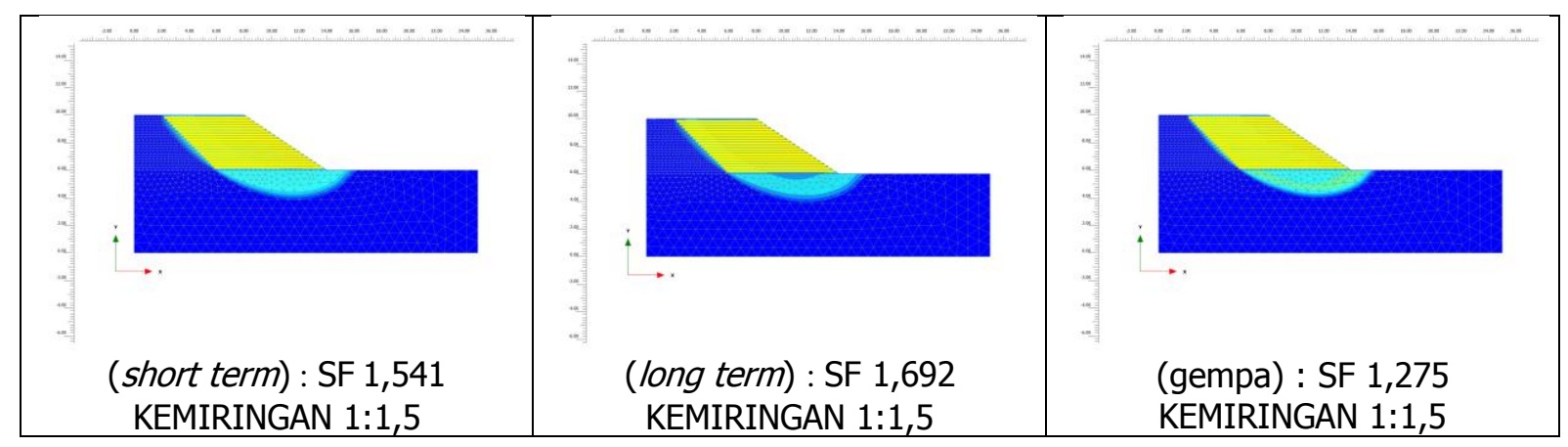

Gambar 11. Pengaruh kondisi short term, long term dan beban gempa pada kemiringan 1:1,5 dengan jarak vertikal geocel/ 0,2 meter 


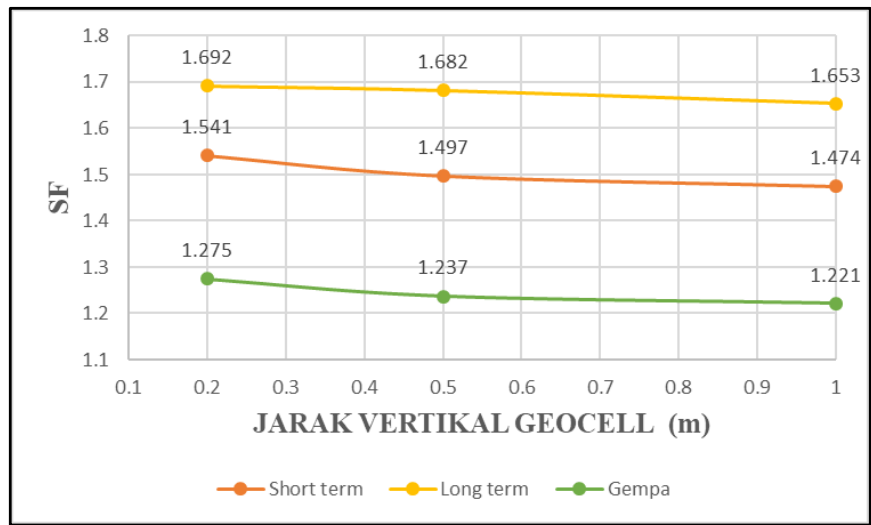

Gambar 12. Grafik pengaruh jarak vertikal terhadap nilai SF dalam kondisi long term dengan konfigurasi horizontal pada kemiringan 1:1,5

Berdasarkan pada Gambar 9, Gambar 10 dan Gambar 11 terjadi perubahan warna pada bidang gelincir dan kenaikan nilai SF pada kondisi long term, serta penurunan nilai SF pada kondisi gempa. Didapatkan nilai faktor keamanan pada kondisi short term atau jangka pendek, sudah dikategorikan aman dikarenakan nilai SF yang didapat $>1,25$. Pada kondisi short term dihasilkan bidang gelincir yang masih mengalami pergeseran tanah sedangkan pada kondisi long term dengan kondisi tanah yang dikonsolidasikan terlebih dahulu atau adanya jarak waktu ketika penimbunan lapis tanah berikutnya mengubah bidang gelincir menjadi lebih aman yaitu menguranginya pergeseran pada tanah. Pada kondisi long term mengalami kenaikan nilai SF dengan rata-rata meningkat $15 \%$ dari kondisi short term. Kondisi gempa dilakukan setelah penimbunan telah selesai dilakukan, beban gempa ditempatkan pada titik lereng yang memiliki lemah mengalami longsor. Data tanah yang berlokasi di Tanah Merah ini dapat dikatakan aman terhadap adanya getaran atau beban gempa, dikarenakan nilai faktor keamanan memenuhi syarat minimum yaitu nilai SF-nya $>1,1$ dengan menggunakan model pseudostatik dan menggunakan koefisien seismik yang didapatkan dari percepatan puncak dari permukaan $(P G A)$ dengan penentuan kelas situs pada lokasi tanah tersebut.

Analisis yang dilakukan pengecekan terhadap tiga kondisi pada pemodelan ini adalah mengetahui perbedaan kenaikan faktor keamanan pada kondisi short term, long term dan gempa, sehingga mengetahui kenaikan pada kondisi long term dan mengetahui penurunan pada kondisi gempa dengan rata-rata penurunan sebesar $20 \%$ dari kondisi short term. Berdasarkan Gambar 12 kenaikan nilai faktor keamanan pada kondisi long term diakibatkan adanya konsolidasi pada tanah timbunan yang dimana tanah tersebut sudah dalam kondisi yang terdisipasi atau konsolidasi tersebut dapat memperkuat kondisi tanah timbunan sehingga semakin padat dan kokoh sehingga lereng pada kondisi long term akan mengalami kenaikan nilai faktor keamanannya dan menanggulangi pergeseran pada tanah. Penurunan nilai faktor keamanan yang terjadi pada kondisi gempa, ditunjukan pada grafik tersebut menghasilkan garis pada grafik berada di bawah nilai faktor keamanan kondisi shor term yang diakibatkan adanya getaran dari beban gempa sehingga tanah timbunan pada lereng terjadi pergerakan dan membuat faktor keamanannya menurun, tetapi nilai faktor keamanan yang didapatkan telah memenuhi kriteria minimum faktor keamanan akibat gempa yang telah ditetapkan pada SNI 8460:2017.

\section{KESIMPULAN}

Setelah dilakukan analisis stabilitas lereng yang yang diperkuat menggunakan geocell pada tiga jenis kemiringan dengan satu jenis model tanah yaitu tanah lempung, maka dapat ditarik kesimpulan sebagai berikut: 
1. Nilai SF terbesar dari ketiga jarak vertikal geocel/ yang digunakan rata-rata terdapat pada jarak yang paling rapat yaitu jarak 0,2 meter; dikarenakan jarak yang semakin rapat akan menanggulangi kondisi yang kritis pada lereng agar semakin aman dan jarak yang semakin rapat juga dapat menaikan nilai SF dengan rata-rata sebesar $7 \%$.

2. Adanya perkuatan geocell dengan masing-masing nilai kuat tarik yang dilakukan dalam pemodelan meningkat nilai SF lereng dengan rata-rata $30 \%$. Ini menunjukan bahwa perkuatan lereng menggunakan geocel/ sangat efektif jika ditinjau dari faktor keamanan stabilitas global. Nilai faktor keamanan yang paling efektif dan efisien didapat pada pemodelan kuat tarik 14,5 MPa; panjang geocell 6 meter; dan jarak vertikal geocell 1 meter dikombinasikan pemasangan geocell; menghasilkan nilai SF yang aman dan lebih besar dari batas minimum SF-nya.

3. Nilai faktor keamanan pada kondisi gempa terjadi penurunan rata-rata sebesar $20 \%$ dari kondisi short term, namun nilai SF yang diperoleh terdapat pada nilai yang aman untuk lereng yang mengalami gempa.

4. Pemilihan jenis tanah pada penelitian stabilitas lereng dengan jenis tanah lempung cocok digunakan perkuatan menggunakan geocell yang dimana ketika uji ketahanan gempa pada software PLAXIS 2D mampu menahan gaya horizontal dari beban gempa tersebut.

\section{DAFTAR RUJUKAN}

Anhui Elite Industrial Co.,Itd. (2020, Oktober 15). Plastic HDPE Geocell. Retrieved Oktober 15, 2020, from ELiTE-iNDUS: https://www.ahelite.com/Plastic-HDPE-Geocellpd403734.html

Badan Standardisasi Nasional. (2017). SNI 8460:2017 tentang Persyaratan Perancangan Geoteknik. Jakarta: Badan Standardisasi Nasional.

Brinkgreve, R. B. (2016). PLAXIS 2016. Netherlands: PLAXIS.

Cook, R. D. (1990). Konsep dan Aplikasi Metode Elemen Hingga. (B. Suryoatmono, Trans.) Bandung: PT Eresco.

Dash, S. K., Krishnaswamy, R. N. \& Karpurapu, R. (2001). Bearing capacity of strip footings supported on geocell-reinforced sand. Geotextiles and Geomembranes, 19(4), 235256.

Departemen Pekerjaan Umum. (2009). Pedoman Konstruksi dan Bangunan No. 003/BM/2009 tentang Perencanaan dan Pelaksanaan Perkuatan Tanah dengan Geosintetik. Jakarta: Departemen Pekerjaan Umum.

Mehdipour, I., Ghazavi, M. \& Moayed, R. Z. (2013). Numerical study on stability analysis of geocell reinforced slopes by considering the bending effect. Geotextiles and Geomembranes, 37, 23-34.

PT. Pandu Equator Prima Geosynthetics Engineering. (2020, Oktober 15). Geocell. Retrieved Oktober 15, 2020, from Pandu Equator: https://pandu-equator.com/geocell/

Rahardjo, P. P. (2002). Manual Kestabilan Lereng. Bandung: GEC: Universitas Katolik Parahyangan. 